\title{
Looking for Evidence of Human Capital (Or the Lack Thereof) in College/University Degrees Held by Managerial Level Employees
}

\author{
Ernie Stark and Paul P. Poppler \\ Logikos \& Experientia \\ Jennifer Aden Murnane \\ Capital Analytics
}

\begin{abstract}
This paper reports a field study of 17 recognized "Employers of Choice" in a Midwestern metropolitan area of the U.S. that examined overarching assumptions regarding the relationship between college/university degrees and job performance. Using data gathered from 129 matched pairs of managerial employees and their immediate superior, a multivariate general linear model was employed to test hypotheses concerning core job performance and contextual job performance. After controlling for the influence of potential confounding variables, results indicated a statistically significant positive relationship between holding an undergraduate degree and measures of job performance (both task and contextual), but the relationship was complicated by an interaction with the gender of the respondent. Further, the effect size of the significant relationships was rather small and this raises issues regarding the practical significance of undergraduate degrees on job performance. The paper concludes with a discussion of the implications of this study regarding assumptions about college and university degrees and human capital.
\end{abstract}

Keywords: Human capital, higher education, job performance.

\section{Introduction}

As early as 1927 , formal schooling was related to socioeconomic advancement and the investment of individual resources into attaining a diploma was considered a distinct advantage for salary attainment (Bills, 2003). More recently, a noteworthy line of research has documented individual returns on investment of a formal education. $\mathrm{Ng}$, Eby, Sorensen, \& Feldman (2005) found that the level of an individual's educational attainment predicts career success as measured by promotions within the same organization. Blundell, Dearden, Meghir, \& Sianesi (1999) concluded that a formal education confers significant wage advantages to individuals and in developed western countries the average gross rate of return on a year's additional study could range from 5 to 10 percent on the investment. Goss (2011) estimated that among adults age 18 and older in the U.S. those with a bachelor's degree will earn, on average, double the amount earned by those with a high school diploma. Work by Oreopoulos and Salvanes (2011) goes even further by suggesting a positive relationship between nonpecuniary 
outcomes (e.g. sense of achievement, job satisfaction, occupational prestige, etc.) and increasing years of college attendance when controlling for the influence of income.

There appears to be little doubt that personal investment in a college diploma is a logical decision given the expected payout. However, seldom addressed in the literature are these two questions: From the perspective of the employer, what factors drive the willingness to make premium wage bids for college educated workers and are such bids justified by the outcomes?

\section{Education as Human Capital}

A relationship between a college education and effective job performance is a widely accepted supposition among human resource practitioners (Truxillo, Bennett, \& Collins, 1998) and reflects thinking about thinking about the concept of human capital.

The emerging theories of human capital are derived from Penrose's $(1959 ; 1995)$ Resource Based Value (RBV) theory of strategy that asserts the true sources of an organization's competitive advantages lie within its specific human, organizational, and physical resources, as opposed to the Industrial Organization (I/O) model of strategy espoused by Bain (1969). The concept of human capital, as it relates to an organization, includes the "collective sum of the attributes, life experience, knowledge, inventiveness, energy, and enthusiasm that people invest in their work" (Weatherly, 2003, p. 1). Other components have been added to the definition of human capital including know how, capabilities, expertise, personality, competencies, skills, qualifications, ability to learn, and network of contacts (Dzinkowski, 2000; Mayo, 2005). The Value Platform model, developed by Edvinsson, St. Onge, Armstrong, and Petrash (as cited in Edvinsson \& Malone, 1997), addresses human capital's role as a foundational element to grow organizational capital.

This supposition postulates that employee knowledge, skills, and abilities (KSAs) are internal and inimitable organizational resources that can be applied to achieve strategic competitive advantages (Boudreau \& Ramsted, 2006; Bush, Green, \& Hart, 2001; Dierickx \& Cool, 1989; Pfeffer, 1994), provided that employees are motivated to pursue organizational goals such as customer satisfaction, market share, profitability, and environmental sustainability (Heneman \& Judge, 2009). Unfortunately, there is little understanding of how human capital manifests itself across organizational levels (Ployhart \& Moliterno, 2011), and the situation is further clouded by the challenge of comparing measures of human capital across organizations given that all measures of human capital are internal and company specific (Bechtel, 2007; Kraaijenbrink, Spender, \& Groen, 2010) and are often based in the organization's normative claims that do not meet numerical or monetary measurement for systematic comparison or transparent financial leverage (Bechtel, 2007; Royal \& O'Donnell, 2008).

A key assumption in the discussion is that formal college education produces qualifications and knowledge (i.e., human capital) for which an employer is willing to pay a premium with expectations of gaining future returns in the form of enhanced job performance than contributes to firm productivity (Blundell et al.,1999). In 1979, Collins noted that education credentials had evolved as a preferred means for sorting and 
selecting workers in the American labor market, and in 2002 Wolf argued that college and university degrees have become for employers all over the world a way of ranking, screening, and selecting people. Today, a college/university degree is a short-hand signal to employers that the holder represents a desirable degree of human capital that may serve a productive purpose for the organization ( $\mathrm{Ng} \&$ Feldman, 2009). Thus, as evidenced by documented wage differentials between degreed and non-degreed workers, it is reasonable to conclude that assigning a premium wage bid to college/university degrees has become a standard practice in human resource management and is justified by assumptions underlying the theory of human capital.

Unfortunately, over the past two decades there has been a glaring lack of research directly examining if the knowledge and expertise assumed present in a person with a college/university degree has a relationship to job performance of a magnitude that would justify a premium wage bid in the labor market. It appears that such a relationship is assumed as being self-evident, and scholars and employers have been hesitant to ask questions such as: Do highly educated workers contribute to organizational effectiveness more than less educated workers? If so, can the premium cost of staffing with highly educated workers ever be recouped? (Ng \& Feldman, 2009). There has not been a common understanding of what a higher education degree means in economic terms (Lumina Foundation, 2011). More succinctly, we don't actually know today what a college or university degree is worth to employers (Wolf, 2011).

Perhaps one explanation for the scarcity of such research can be found in an observation by Blundell et al. (1999): At the more macro-level, it is extremely difficult to obtain data on firm productivity, competitiveness, and profitability because the relationship between worker productivity and subsequent firm profitability is complex; at a more micro-level, formal education may represent an accumulation of skills in which it is difficult to isolate those skills attributable to the education process and those obtained by experience elsewhere. Summarizing what few studies have been published Berry, Gruys, and Sackett (2006) noted that educational attainment has demonstrated rather low validity levels as a predictor of job performance.

\section{Purpose of this Study}

At the heart of this study is a question about the extent to which a college/university undergraduate degree represents a level of human capital that would justify premium wage bids by employers. Research for this study began prior to the publication of the $\mathrm{Ng}$ and Feldman (2009) meta-analysis that addressed a number of hypotheses reflecting underlying assumptions about postsecondary education inherent in human capital theory. While meta-analysis such as the one conducted by $\mathrm{Ng}$ and Feldman can be considered a quantitative procedure for summarizing or integrating the findings obtained from a literature review of a subject, it can also be correctly considered as more of a synthesis than analysis (Vogt, 1999). Funded by a major nonprofit organization concerned with higher education, the study reported in this paper tested hypotheses comparable to the $\mathrm{Ng}$ and Feldman study, but within a specific population of interest to the researchers. This paper reports the degree to which this analysis within a 
bounded population reflected and differed from the synthesized findings of $\mathrm{Ng}$ and Feldman, and it extends the discussion of the contribution of college/university education into the realm of human capital and strategic human resource management, topics not broached in the $\mathrm{Ng}$ and Feldman analysis.

\section{Constructs and Hypotheses}

\section{Education}

Due to the ambiguity about functional metrics of human capital, education level appears to have become a default measure of human capital. A bachelor's degree is considered an entry requirement into professional fields (Trusty \& Niles, 2004), and in higher-paying jobs such as management, the presence or absence of an undergraduate degree from an accredited higher education institution is often a prerequisite for employment consideration. Grounded assumptions within human capital theory serve as an implied gate-keeping rationale for employer hiring practices; that is, enhanced employee intelligence and knowledge provide advantages to the employer (Hough, 2009). However, from a purely economic perspective, a wealth maximizing firm will pay a premium for employees holding an undergraduate degree only if it expects the return from the investment to be greater than the market rate of interest (Blundell et al., 1999). Thus, there is an expectation that the benefits derived from expenditures in hiring college/university graduates will be at least equal to or exceed the monetary value of such expenditures (Samudhram, Shanmugam, \& Low, 2008).

\section{Core task performance}

Task performance concerns the technical core of one's job (Van Iddekinge \& Ployhart, 2008), the specification of formal job requirements, and, generally, involves a set of behaviors necessary for producing goods or services that provide indirect support for a firm's core technical processes. (Sekiguchi, Burton, \& Sablynski, 2008). The literature suggests that the process of earning a college degree enhances an individual's general intelligence and therefore increases job-related knowledge, both of which are likely to influence core job performance.

Kanfer and Ackerman (2004) theorized that intelligence is manifested in two forms: fluid and crystalized. Fluid intelligence is associated with one's capacity for abstract reasoning and processing complex information. Fluid intelligence is manifested as an ability to solve a problem independent of prior learning, experience, or education. Work by Trusty and Niles (2004) suggests that individuals having high degrees of fluid intelligence (i.e., as evidenced by engagement in intensive math and science courses while in high school) are more likely to gain entrance into a college and stay in college. Thus, by default, individuals holding bachelor's degrees are assumed, on average, to possess a greater degree of fluid intelligence than those who do not hold such degrees, and it appears rational that the premium cost incurred by the employer in bringing an asset such as fluid intelligence to the workplace is justified by presumed future benefits in performance of core tasks. 
Kanfer and Ackerman (2004) define crystallized intellectual ability as comprising the totality of educational and experiential knowledge and including both occupational knowledge and avocational knowledge (e.g., hobbies, music, culture, etc.). Evidence suggests that through the evolution of cognitive knowledge, college work stimulates students' minds and enhances the totality of their crystallized knowledge ( $\mathrm{Ng}$ \& Feldman, 2009). Moreover, Hunter (1992) and Schmidt and Hunter (1998) provided a rationale for speculating that enhanced cognitive abilities gained through the process of earning a college degree facilitates stronger job performance. Nonaka (2002), in his theory of organizational knowledge creation, describes crystallization in terms of interactive and social cognitive processes wherein individual tacit concepts are rigorously analyzed and synthesized to create new knowledge specific to the organization. Acknowledging that cognitive ability might be unimportant to some jobs, Heneman and Judge (2009) reported that they had yet to find such jobs. Thus, an undergraduate degree could also be considered evidence of the holder's greater levels of crystallized intelligence and that the anticipated future benefits in core job performance outweigh the premium costs of hiring college graduates.

Knowledge is also manifested in two forms. Declarative knowledge involves encoding or storing definitions, examples, and rules into long-term memory and using this knowledge in problem solving strategies. Procedural knowledge is the ability to apply and extend declarative knowledge; however, it is mechanistic, not accessed consciously, and can be inferred only by behavior of the actor (McCall, Arnold, \& Sutton, 2008; Ree, Earls, \& Teachout, 1994). A premise associated with earning an undergraduate degree is that the process equips the degree holder with greater levels of both declarative and procedure knowledge than the non-degreed individual $(\mathrm{Ng} \&$ Feldman, 2009). Thus, a bachelor's degree may be considered evidence of the holder's potential to bring value to performance of core tasks beyond the cost incurred by the employer because of the totality of his/her knowledge.

In summary, an employee possessing an undergraduate degree would appear to merit a higher wage bid than an employee not holding such a degree because the degree holding employee signals the potential for bringing to bear on core task performance greater levels of intelligence (both fluid and crystalized) and knowledge (both declarative and procedural).

Hypothesis \#1: Management-level employees holding undergraduate degrees will perform core job tasks at a higher level than will peers not holding an undergraduate degree.

\section{Contextual Job Performance}

Whereas core task performance refers to the basic requirements of the specific job, contextual performance is identified by employee contributions that sustain an atmosphere of cooperation and interpersonal support (Organ, Padsakoff, \& MacKenzie, 2006). Highly valued assets acquired by an individual through the postsecondary 
educational process hold the promise of producing advantages for their employers, and prominent among the anticipated advantages is a potential to contribute to enhancement of the social and psychological context that supports performance of job related tasks ( $\mathrm{Ng} \&$ Feldman, 2009). Contextual job performance takes the form of interpersonal facilitation or job dedication, encompasses self-discipline behaviors related to rule compliance and use of time (Organ, et al., 2006), and it is believed to influence evolution of capital available to the employer by advancing or retarding collective goal orientation and shared trust (Reed, Srinivasan, \& Doty, 2009). The literature provides reason to consider that through the process of postsecondary education individuals develop characteristics that contribute to enhancement of contextual job performance.

A college/university degree may be viewed by an employer as evidence of the holder's potential to contribute to the maintenance and enhancement of the social and psychological context that supports performance of job related tasks. College graduates have demonstrated, over time, a tendency to attach greater importance to helping others and developing good relations with others than do non-graduates (Johnson \& Elder, 2002). Research also suggests that individuals with college/university degrees are more likely to demonstrate higher levels of conscientiousness (Dudley, Orvis, Lebiecki, \& Cortina, 2006), be more likely to adhere to work rules related to attendance and protection of firm property (Konovsky \& Organ, 1996), and be less likely to put their coworkers into dangerous situations by ignoring safety instructions (Oh \& Shin, 2003). Further, research by Harel and Baruch (1993) suggests that earning a college degree may have a positive influence on measures of professionalism and organizational commitment. In short, there is evidence suggesting that holding an undergraduate degree may enable individuals to make a greater contribution, on average, to the environment in which job tasks are conducted than individuals not holding such a degree, and a rational argument could be put forth that employers are willing to pay a premium to secure this asset because of assumed future benefits.

Hypothesis \#2: Management-level employees holding undergraduate degrees will demonstrate higher levels of contextual job performance than will peers not holding an undergraduate degree.

\section{Population and Sample}

Data for this study were secured from a population of 17 recognized "Employers of Choice" in the geographical area served by a university in a Midwestern metropolitan area of the U.S. These firms were identified as "Employers of Choice" because of their recognized ability to hold top talent of long periods of employment as per Herman and Gioia, (2000). These employers responded to an invitation to participate in a study of managerial behavior funded by a major nonprofit charitable organization. The industries and sectors represented by the participants included data processing, transportation, manufacturing, and governmental services. The intended sample consisted of 153 randomly selected matched pairs (subordinates in managerial positions and their immediate supervisor) in which the immediate supervisor responded to a questionnaire 
about the attributes of the subordinates. Missing data from 26 matched pairs resulted in an achieved sample of 129 matched pairs used in this study.

\section{$\underline{\text { Measures }}$}

\section{Dependent Variables}

As a precursor to this specific study, an initial survey of approximately 150 corporate executives nationwide in the U.S. inquired about the most desirable knowledge, skills, abilities and attributes in managerial level employees. Fifty of the executives responded, and based on a thematic analysis of the data, a list of common 28 attributes was determined. In the next step, 100 CEOs of firms in a four-state region of the U.S. Midwest were administered a survey which asked them to rank order the list of 28 managerial attributes so as to reflect their relative importance in achieving their firm's strategic business objectives in the coming five years. Fifty-seven responded to the survey, and through a frequency count, a list of 10 priority behaviors evolved from this data.

Working from this priority list, a search of the literature was undertaken for previously published measures believed reflective of these 10 attributes. Measures were gleaned from the literature and integrated with original measures created by a consulting firm assisting with the project. Thus, multiple measures of the 10 priority attributes were included in the survey and given to the dyadic supervisor asking them to rate their subordinate on these measures.

Data generated by dyadic leaders were subjected to a principle component factor analysis, and the resulting factors were orthogonally rotated to maximize differentiation as per Tabachnick and Fidell (2007). A 14-factor solution explaining $74 \%$ of the common variance in the survey items was indicated on the basis of a minimum eigenvalue of 1 , examination of the scree plot, and the interpretability of the factors. Toward achieving parsimony from the results of the factor analysis, only factors with Eigenvalues greater than 1.80 were considered acceptable for this particular study, and this left five factors explaining approximately $59 \%$ of the common variance in the survey items. To further differentiate these factors, items within each factor that loaded at less than .50 or loaded on two or more factors separated by values of less than .20 were dropped from the analysis.

Core task performance. One of the five remaining factors clustered around six items identified with an original projective measure by Atwater, Ostroff, Yammarino, and Fleenor (1998) and was determined to be an adequate depiction of managerial effectiveness. On these six items, supervisors reported their perceptions regarding how a subordinate manager would perform in important job related situations as compared to his/her peers. A decision was made that these six items addressed the construct of core task performance for managerial personnel in this study. For instance, one item inquired about how the subordinate manager would perform upon being given responsibility for constructing a response to an important request for proposal. A six- 
point response with anchors of 1 being "among the worst" and 6 being "among the best" was used in this scale. A high score on this measure was interpreted as preeminence in performance of core managerial tasks and a low score was interpreted as less than desirable performance in these activities. The six items in this measure entitled "Managerial Effectiveness" demonstrated a Cronbach's alpha of .96.

Contextual job performance. Another of the remaining five factors clustered around five items associated with Niehoff and Moormen's (1993) original measure of organizational citizenship behavior. The scale measures behaviors that demonstrate going beyond the narrow confines of one's job description, showing unselfish concern for the welfare of others, acting in consideration and politeness, showing concern for doing what is right and just, and displaying a concern for the affairs and well-being of the firm. Given that Organ et al. (2006, p. 39) concluded that such behaviors are indicative of employee contributions that go beyond the strict terms of the job or what the job is said to actually require, it was determined that this factor adequately addressed the construct of contextual job performance. For instance, one item inquired of the dyadic supervisor how accurate the statement is that the subordinate obeys company rules, regulations, and procedures even when no one is watching. Responses ranged from 1 being "totally inaccurate" to 6 being "extremely accurate." A high score on this measure was interpreted as ascendancy in performance of contextual job activities and a low score was interpreted as less than desirable performance in these activities. The five items in this measure entitled Organizational Citizenship demonstrated a Cronbach's alpha of .85 .

\section{Independent Variables}

Earned undergraduate degree. Of primary interest was the influence of holding or not holding a bachelor's degree on measures of core job performance and contextual job performance. Subordinate managers in this study were administered a separate survey instrument in which they reported if they did or did not hold an undergraduate degree. If they answered "yes", they listed the institution of higher education from which they earned that degree. All institutions identified in the survey were verified as having accreditation by their appropriate regional accrediting agency. Eighty respondents held an undergraduate degree and 49 held no such degree.

Race. Given that research has demonstrated the influence of race on performance appraisal to some limited extent (Hargis, Baltes, \& Levi, 2006; Roberson \& Block, 2001) and that performance evaluations influence employee development (Druskat \& Wolff, 1999; Latham \& Wexley, 1994), race was identified as an independent variable in order to account for its influence on measures of core job performance and contextual job performance and allow for a possible interaction with holding or not holding an undergraduate degree. Race was determined by response to a survey question asking subordinate managers to select one of 10 racial groups with which they most closely identified. It was deemed necessary to restructure the data regarding race in a manner that would provide adequate power for examining its potential influence on the relationship between education and the dependent variables in this study. Thus, all 
those subordinate managers indicating European ancestry were classified as White and all who indicated other racial identities were classified as non-White. This decision was considered reflective of the literature on relational demography that speaks extensively of Whites and non-Whites (see: McDermott \& Samson, 2005; Ployhart \& Holtz, 2008; Wong \& Cho, 2005). Sixty-five respondents were classified as White, and 64 were classified as non-White.

Gender. Because there is much scholarly discussion regarding the differing workplace experiences of men and women and the degree to which such experiences produce less desirable job and career outcomes for females ( $\mathrm{Ng} \&$ Feldman, 2009), gender was identified as an independent variable in order to account for its influence on measures of core job performance and contextual job performance. Fifty-seven of the subordinate managers in this study responded as being male and 72 as female.

\section{Control Variables}

Position tenure. Meyers and Conner (1992) and Stark (2009) suggest that accumulated work experience over time may produce strategies and procedures representing aspects of crystallized intelligence that enhance job performance. To account for the influence of job tenure in this study, subordinate managers were asked to indicate how long they had been in their current job. Responses were categorized as (a) less than one year, (b) more than one year but less than three years, (c) more than three years but less than five years, (d) more than five years but less than seven years, and (e) more than seven years.

Training and certification. Certification attained through structured training represents an aspect of education distinct from the experience of earning an undergraduate college/university degree. Certification is likely to influence core job performance because its purpose is most often to enhance through training the skill level of employees on specific core job tasks (Blundell et al., 1999; Ng \& Feldman, 2009). To account for the influence of training on job performance, subordinate managers were asked to indicate the number of technical or professional certifications (i.e. Certified Microsoft Technician, Senior Human Resource Professional, Certified LAN Administrator, etc.) they had earned (1, 2, 3, 4, or more than 4).

Graduate degree. Having a master's degree has demonstrated a large positive effect on promotional probabilities (Spilerman \& Lunde, 1991). Assuming that the increased promotional prospects associated with attainment of a graduate degree represent a belief that increased job-related knowledge has occurred in the process, it was necessary to control the variation in job performance related to having completed a graduate degree. Subordinate managers were asked if they had earned a graduate degree and responded "Yes" or "No".

Age. Recent work by Stark $(2009,2008)$ suggests that increasing age has an influence on how managers evaluate the performance of direct reports (not as previously 
asserted, but more positively). Subjects in this study reported their age as either 20-29, $20-39,40-49,50-59$ or over 60 years of age.

\section{Methods}

A multivariate general linear model (MGLM) in which the control variables were entered as covariates was used to test the two hypotheses in this study. This approach was deemed appropriate given that the goal was to examine whether variation observed in the two dependent variables is influenced by variation in the independent variables. That is, holding all else constant, are the mean differences in the composite dependent variables at different levels of the independent variables larger than expected by

\section{$\underline{\text { Results }}$}

Table 1

Descriptive and correlations (raw scores from original sample)

\begin{tabular}{|c|c|c|c|c|c|c|c|c|c|c|}
\hline Variable & $\mathrm{N}$ & Mean & SD & $\begin{array}{c}\text { Mgt } \\
\text { Effect }\end{array}$ & $\begin{array}{c}\text { Org } \\
\text { Citizen }\end{array}$ & Gender & Race & $\begin{array}{l}\text { Under } \\
\text { Grad }\end{array}$ & $\begin{array}{c}\text { Grad } \\
\text { Degree }\end{array}$ & $\begin{array}{l}\text { Prof } \\
\text { Cert }\end{array}$ \\
\hline $\begin{array}{l}\text { Mgmt } \\
\text { Effect }\end{array}$ & 151 & 4.23 & 1.09 & & & & & & & \\
\hline Org Citizen & 153 & 4.72 & 0.93 & $.608^{* *}$ & & & & & & \\
\hline Gender & 153 & 1.55 & 0.55 & $-.170^{*}$ & -.010 & & & & & \\
\hline Race & 155 & .0 .49 & .50 & -.007 & $.164^{*}$ & .110 & & & & \\
\hline $\begin{array}{l}\text { Bachelor } \\
\text { Degree }\end{array}$ & 154 & 1.37 & 0.48 & .134 & $218^{* *}$ & .062 & .111 & & & \\
\hline $\begin{array}{l}\text { Grad } \\
\text { Degree }\end{array}$ & 143 & 1.83 & .38 & -.028 & .048 & $.234^{\star *}$ & .065 & .010 & & \\
\hline $\begin{array}{l}\text { Prof. } \\
\text { Certificates }\end{array}$ & 144 & 1.53 & 0.38 & $.237^{\star \star}$ & $.189^{*}$ & .137 & -.066 & $-.176^{*}$ & .107 & \\
\hline $\begin{array}{l}\text { Job } \\
\text { Tenure }\end{array}$ & 153 & 2.29 & 1.17 & .086 & .041 & .052 & -.097 & .139 & -.024 & .070 \\
\hline
\end{tabular}

$* \mathrm{p}<.05$

$* * \mathrm{p}<.01$

random chance? Using the control variables as covariates allowed a form of "what if" analysis by asking what would happen if all cases scored equally on the covariates so 
that the effect of the independent variables on the dependent variables over and beyond the covariates can be isolated (Tabachnick \& Fidell, 2007). Prior to analysis, the dependent variables were converted to a standardized score, and because the control variables were used as covariates, they were dummy coded so that they constituted continuous variables as per Cohen, Cohen, West, and Akin (2003).

Assumptions of Normality

The measures of Managerial Effectiveness and Organizational Citizenship demonstrated kurtosis and skewness values of less than 1, and these values were interpreted as indicative of a normal distribution. Levene's test of equality of error variance produced non-significant results (alpha $=0.05)$ giving indication that error variance on the dependent variables was equal across all groupings of the independent variables.

Table 2

Multivariate Test Using Wilks' Criterion

\begin{tabular}{|c|c|c|c|c|c|}
\hline Variable & $\begin{array}{l}\text { Wilks' } \\
\text { value }\end{array}$ & $\begin{array}{c}\mathbf{F} \\
\text { value }\end{array}$ & $\begin{array}{l}\text { Hypothesized } \\
\text { df }\end{array}$ & Error df & $\eta^{2}$ \\
\hline $\begin{array}{l}\text { Position } \\
\text { Tenure }\end{array}$ & .998 & .719 & 2 & 118 & .012 \\
\hline $\begin{array}{l}\text { Prof. } \\
\text { Certificates }\end{array}$ & .878 & $8.204^{* \star \star}$ & 2 & 118 & .122 \\
\hline $\begin{array}{l}\text { Grad. } \\
\text { Degree }\end{array}$ & .994 & .372 & 2 & 118 & .006 \\
\hline Gender & .909 & $5.894^{\star \star}$ & 2 & 118 & .091 \\
\hline Age Group & .973 & 1.663 & 2 & 118 & .027 \\
\hline Race & .983 & 1.019 & 2 & 118 & .017 \\
\hline $\begin{array}{l}\text { Undergrad. } \\
\text { Degree }\end{array}$ & .942 & $3.636^{*}$ & 2 & 118 & .058 \\
\hline $\begin{array}{l}\text { Gender } x \\
\text { Undergrad } \\
\text { Degree. }\end{array}$ & .884 & $7.720^{\star \star \star}$ & 2 & 118 & .116 \\
\hline $\begin{array}{l}\text { Race } x \\
\text { Undergrad } \\
\text { Degree. }\end{array}$ & .964 & 2.219 & 2 & 118 & .036 \\
\hline
\end{tabular}

${ }^{*} p<.05$

${ }^{* *} p<.01$

${ }_{* * *} \mathrm{p}<.001$ 
Multivariate tests were conducted using a Wilks' criterion (See Table 2). The composite dependent variable was significantly influenced by only one covariate, the number of professional certificates $\left(F(2,118)=8.20, p<.001\right.$, partial $\left.\eta^{2}=.12\right)$. Controlling for the influence of the covariates, gender demonstrated a significant influence on the composite dependent variable $\left(F(2,119)=5.90, p<.01\right.$, partial $\left.\eta^{2}=.09\right)$, and while having a bachelor's degree also demonstrated a significant influence $(F(2,118)=3.64$, $\mathrm{p}<.05$ ) on the combined variables, the association was small with an approximate partial $\eta^{2}=.06$. Finally, after controlling for the influence of the covariates and the main effects, the composite dependent variable was significantly influenced by an interaction between gender and having a bachelor's degree $\left(F(2,118)=7.20, p<.001\right.$, partial $\eta^{2}=$ .11). A lack of fit test produced non-significant results indicating that the data adequately fit the model.

To summarize, after controlling for the influence of the covariates in this sample, the influence of gender on the combined measures of core job tasks and contextual job performance was beyond that attributable to random chance and accounted for about $9 \%$ of variance. The influence of the undergraduate degree on the combined variance of these two measures was also beyond that attributed to random chance but accounted for about $6 \%$ of the variance. The interaction of gender and an undergraduate degree on the combined measures of job performance was statistically significant and accounted for approximately $11 \%$ of the variance.

To further investigate the statistically significant main effects and interaction, a betweensubject test of effects was conducted. The gender of the respondent demonstrated a

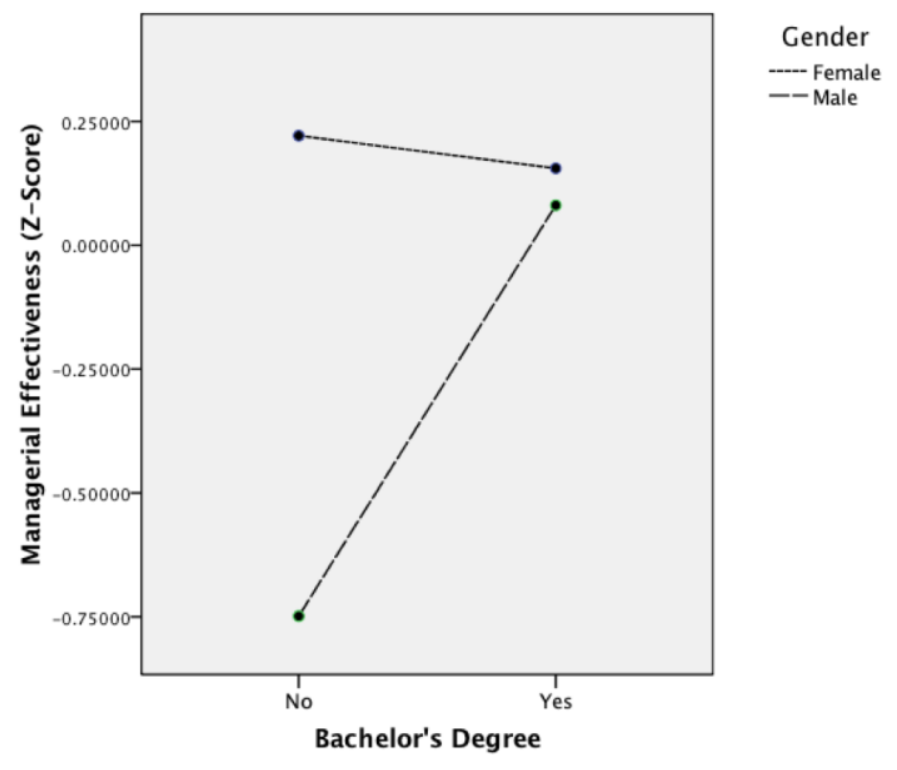

Figure 1. Interaction of gender and bachelor's degree on managerial effectiveness 
significant influence only on the measure of Managerial Effectiveness $(F(1,119)=8.59$, $\mathrm{p}<.01$ ) producing a small effect size (partial $\eta^{2}=.076$ ). On average, females were scored higher on this measure than males with a mean difference of .56 $(p<.01)$ or about $1 / 2$ of one standard deviation. Holding a bachelor's degree demonstrated a significant influence on both Organizational Citizenship $(F(1,119)=6.81, \mathrm{p}<.05$, partial $\left.\eta^{2}=.054\right)$ and Managerial Effectiveness $\left(F(1,119)=4.72, p<.05\right.$, partial $\left.\eta^{2}=.038\right)$. On the measure of Organization Citizenship, respondents holding a bachelor's degree were scored higher than those not holding a bachelor's degree with a mean difference of .47 $(p<.05)$ or about $1 / 2$ of one standard deviation. On the measure of Managerial Effectiveness, respondents holding a bachelor's degree were scored higher than those not holding the degree with a mean difference of $.37(p<.05)$ or less than one-half of one standard deviation. The interaction effect between gender and holding a bachelor's degree demonstrated a significant influence only on the measure of Managerial Effectiveness $\left(F(1,119)=5.45, p<.05\right.$, partial $\left.\eta^{2}=.052\right)$.

Figure 1 provides a graphic of this interaction. It would appear from this interaction that on the measure of core job performance (Managerial Effectiveness), not holding a bachelor's degree undermined male managers more than female managers without such a degree. On the other hand, once a male manager secured a bachelor's degree, it appeared to remove any perceived difference about core job performance when compared with similarly situation female managers.

To summarize the between-subject effects, in this sample holding an undergraduate degree demonstrated a relationship beyond that attributable to random chance with both the individual measures of contextual job performance and core job performance. It is, however, germane to note that while support was found for both hypothesis \#1 and \#2 via statistical significance, the practical significance could be debated. That is, holding an undergraduate degree accounted for only about $4 \%$ of the variance in the measure of core job performance and $5 \%$ of the variance in the measure of contextual job performance. Interpretation of the relationship between holding a bachelor's degree and core job performance is further complicated by the interaction shown in Figure 1, and understanding this interaction certainly merits further investigation.

\section{Discussion}

\section{Complexities in the Results}

The results of this study reflect some of the findings reported by the $\mathrm{Ng}$ and Feldman (2009) meta-analysis. As in the $\mathrm{Ng}$ and Feldman synthesis, whatever intelligence (crystallized or fluid) and knowledge (declarative or procedural) associated with the postsecondary education experience (represented in this study by the presence or absence of a bachelor's degree) appeared positively related to core job performance, and degree holders appeared more likely to contribute to the contextual aspects of job performance than none degree holders. In this study, as in the $\mathrm{Ng}$ and Feldman 
synthesis, job tenure did not appear to influence the relationship between education and performance.

Further, as found by $\mathrm{Ng}$ and Feldman, the positive relationship between a college education and core job performance appeared stronger for men than for women, and this raises a perplexing question as to why an undergraduate degree might benefit estimation of the core job performance of women to a lesser extent than men. A recent study (DePater, Van Vianen, Fischer \& Van Ginkel, 2009) found a positive relationship between the level of challenging tasks undertaken on the job and related career success (as measured by supervisor evaluations of employee potential for career advancement). In this study done with Dutch university students, women performed fewer challenging tasks than men did and the study noted that gender differences early on in careers can establish larger discrepancies in career advancement potential as their careers progress. Perhaps the gender differences in managerial effectiveness found in the present study are not linked to the attainment of a bachelor's degree but likely can be explained as a result of the acceptance of more challenging tasks or some other variables.

Should an employer in the population from which this sample was secured assume that, on average, paying a premium wage for a manager holding a bachelor's degree ensures job performance beyond that expected of non-degreed managers? In this sample, holding constant all the other variables thought to influence job performance, holding an undergraduate degree accounted for only $6 \%$ of variance in the composite measure of job performance, but that leaves $94 \%$ of the variance unexplainable by this variable. This unexplained proportion of variance is commonly referred to as "error" in most general linear models and represents all the other "things" going on in the model. One must question why the error term is so large in relation to the amount of variance in composite job performance explained by holding an undergraduate degree. Further, if there is reason to assume, as suggested by Blundell et al. (1999), that employers are likely to make wage bids to college/university degree holders ranging from 20 to 40 percent (assuming a four or five year program of study) above what is required to employ non-degreed individuals in the same job, does an average difference of less than one-half of one standard deviation between degree holding managers and nondegree holding managers in evaluation of their core task performance in this study justify such a premium? Even Echols (2008), a vocal proponent of postsecondary education as an indicator of human capital for employers, acknowledges that in the presence of such a large error term it is extremely difficult to attach value to the contribution of an undergraduate degree and not to something else. Within the population represented in this study, it may be reasonable to suggest that the difference in job performance between managers holding a college/university degree and those not holding such a degree is only of marginal consequence and calls into question the economic value of paying a premium wage to degree holders. 


\section{Questions about Human Capital in College/University Graduates}

That the human capital generally assumed inherent in college/university degree holders within the population represented in this study demonstrated such a small practical impact on the combined measures of job performance (core and contextual) certainly merits further discussion. The authors advance three perspectives deemed worthy of consideration.

First, there may be reason to question exactly what a college/university degree signals to potential employers. At a minimum, it should signal an individual's completion of a prescribed course of study. Beyond that, conclusions are more difficult to justify. It would not be too great of an exaggeration to state that there is general consensus in the U.S. that virtually everyone who has the motivation and stamina should pursue a college/university degree as witnessed by the fact that nationwide among adults over the age of 25, 1 in 4 has obtained a bachelor's degree or higher (U.S. Dept. of Labor, 2009). However, Hough (2009) cites Charles Murray's recent book entitled Real Education charging that too many unprepared individuals in the U.S. are pushed into college resulting in colleges diluting the rigor of their degree programs to ensure socially acceptable graduation rates. Support for this charge is found in work by Babcock and Marks (2008) documenting steep declines in academic time investment by full-time college students at four-year institutions in the U.S., work by Arum and Roksa (2011) concluding that a large number of students show no significant progress on tests of critical thinking and complex reasoning between their freshman and senior years of college, and in the U.S .Department of Education's report to Secretary Margaret Spellings (2006) entitled $A$ Test of Leadership which concluded that too many Americans just aren't getting the education they need and that there exists disturbing signs that many individuals who do earn degrees have not actually mastered the skills expected of college graduates. Finally, in a discussion within The Chronicle of Higher Education on November 8, 2009, Caplan concluded that most college courses teach minimal useful job skills, and the main outcome of earning an undergraduate degree is to signal to employers that one is a hard-working conformist.

Second, perhaps one should reflect on the fact that a single covariate (the number of earned professional certificates) in this study accounted for the largest amount of variance (approximately 12\%) in the composite measure of managerial job performance. Is it likely that there exist surrogates for the influence of a college/university degree on core task and contextual aspects of job performance? Hiring newly minted undergraduates certainly increases the potential for familiarity with recent advances in particular field of study (Milkovich \& Newman, 2008), but degreed individuals cannot be assumed to possess what Gibbons and Waldman (2004) identify as task-specific human capital (i.e., knowledge gained through repeated exposure to a particular set of activities) necessary to rapidly enhance performance beyond minimal expectations. Recent work by Pil and Leana (2009) certainly suggests that job performance may be influenced to a greater extent by individual experiences specific to job demands than by formal educational attainment. Thus, it is likely that there exist substitutes (i.e., technical training institutes, training from professional societies, and 
management seminars) for the influence of an undergraduate degree on job performance, and it might be that an employer's ROI on investment in human capital would be greater when placing a premium on job specific training than on hiring degreed employees. Perhaps this lends supports to Murray's accusation in The Chronicle of Higher Education on November 8, 2009 that the premium wages granted to holders of undergraduate degrees is due more to the associations attached to the degree by the employer than anything the student learned while getting the degree and that certification could substitute for a bachelor's degree and merit the same premium wage bid.

Finally, perhaps it is relevant to reiterate Nordhaug's (1994) statement of some 15 years ago that the actual substance of human capital remains severely under-theorized. Spoken of in generalized terms such as being the aggregate of human knowledge, skills, and aptitudes that may serve productive purposes in organizations, there exists today little beyond earlier postulations about a relationship between investment in human resources and returns on such investments. Whether there is utility to be gained from paying premium wages rates for employees holding college/university degrees requires several considerations, not the least of which is the fundamental question of how an employer defines the "human" as "capital" and what constitutes a "strategic resource." Barney (1981) and David (2008) point out that from a resource-based perspective human capital can not provide a sustainable competitive advantage unless it proves to be valuable, scarce, difficult to imitate, and not easily substituted. Given that nationwide among adults $25 \%$ have obtained a bachelor's degree or higher (US Dept. of Labor, 2009), we would argue that college/university degrees represent a generic form of human capital (Barney \& Wright, 1998) that is rather easily obtained by variety of firms. While such a generic form of human capital may enable parity, it is not likely to result in a competitive advantage. Further, Ployhart and Moliterno (2011) advocate that assuming education constitutes human capital fails to acknowledge macro findings showing that the value of human capital resources is context specific. In short, one does not have to be card-carrying economic determinist to recognize that a firm's economic travails will not likely be resolved through an isolated strategy of employing increasing numbers of workers with college/university degrees (Wolf, 2011).

\section{Limitations and Implications}

First, given that this study was of a specific and bounded population, generalization of the sample results to a larger population should be done with great caution. Second, because this study was cross-sectional in nature, the relationships may be subject to temporal change. Third, we acknowledge that this was a field study rather than an experimental study and it is impossible to fully attribute causality to the findings because we did not manipulate the independent variables nor control for confounding variables by treatment assignment. Nonetheless, MGLM is an accepted procedure to statistically account for the inability to control for confounding variables by treatment assignment (Harlow 2005). Finally, it is not possible to rule out common response bias given that dyadic supervisors completed two separate job measures (core and contextual) for each managerial subordinate. 
While results of this study point toward a possible relationship between postsecondary education and job performance, interpretation of the results of this study is complicated by the interaction of gender and a bachelor's degree explaining a greater proportion of variance in the combined measures of managerial job performance than holding a bachelor's degree alone.

Another limitation is that the study is specific to those in managerial positions instead of other types of organizational positions. Further, no attempt was made to determine if the relationship demonstrated in this study might also be influenced by the educational delivery system (e.g., virtual universities vs. brick and mortar institutions; degree completion programs vs. traditional four/five year programs) or the philosophies associated with the course of study (e.g., liberal arts vs. science). In regards to the possible evolution of human capital arising from such relationships, there is justification for creating and testing theoretical models of moderating and mediating relationships in the path from postsecondary education through core and contextual job performance culminating in measures of human capital. Finally, there is a growing need to develop and test models estimating the contributions of intangibles such as human capital to the final business product or service. As Cascio and Bourdreau (2009) advocated, intangible does not necessarily mean immeasurable. Until we can make such a determination, we will not be able to fully estimate the capital that an employer secures when hiring a college/university graduate over an applicant lacking such a degree.

\section{References}

Arum, R., \& Roska, J. (2011, May 15). Your so-called education. New York Times, p. WK 10.

Atwater, L. E. Ostroff, C. Yammarino, F. J., \& Fleenor, J. W. (1998). Self-other agreement: Does it really matter? Personnel Psychology, 51(3), 557-591.

Babcock, P., \& Marks, M. (2008). Leisure college, USA: The decline in student study time. American Enterprise Institute for Public Policy Research: Education Outlook, 7, 2-7. Retrieved on March 31, 2011 at http://www.econ.ucsb.edu/ babcock/LeisureCollege2.pdf.

Bain, J. S. (1969). Industrial organization. New York, NY: Wiley \& Sons.

Barney, J. (1991). Firm resources and competitive advantage. Journal of Management, 17(1), 99-120.

Barney, J. B., \& Wright, P. M. (1998). On becoming a strategic partner: The role of human resources in gaining competitive advantage. Human Resource Management, 37(1), 31-46.

Bechtel, R. (2007). The market based valuation of the human resource. German Journal of Human Resource Research, 21(3), 206-231.

Berry, C. M., Gruys, M. L., \& Sackett, P. R. (2006). Educational attainment as a proxy for cognitive ability in selection: Effects on levels of cognitive ability and adverse impact. Journal of Applied Psychology, 9(3), 696-705. 
Bills, D. B. (2003). Credentials, signals, and screens: Explaining the relationship between schooling and job assignment. Review of Educational Research, 73(4), 441-469.

Blundell, R., Dearden, L., Meghir, C., \& Sianesi, B. (1999). Returns from education and training to the individual, the firm, and the economy. Fiscal Studies, 20(1), 1-23.

Boudreau, J. W., \& Ramstad, P. M. (2005). Talentship: Talent segmentation and sustainability: A new HR decision science paradigm for a new strategy definition. Human Resource Magazine, 44(2), 129 -136.

Boyatzis, R. E., Cowen, S. S., Kolb, D. A., \& Associates (1995). Innovation in professional education. San Francisco, CA: Jossey-Bass.

Bush, C. G., Greene, P. G., \& Hart, M. M. (2001). From the initial idea to unique advantage: The entrepreneurial challenge of constructing a resource base. Academy of Management Perspectives, 15(1), 64-78.

Cascio W. F., \& Boudreau, J. V. (2008). Investing in people: Financial impact of human resource initiatives. Upper Saddle River, NJ: Pearson.

Cohen, J., Cohen, P. West, S. G., \& Aiken, L. S. (2003). Applied multiple regression/correlation analysis for the behavioral sciences. Mahwah, $\mathrm{NJ}$ : Lawrence Erlbaum Associates.

Collins, R. (1979). The credential society. New York, NY: Academic Press.

David, F. (2008). Strategic management: Concepts and cases. Upper Saddle River, NJ: Pearson Education Publishers.

DePater, I. E., VanVianen, A. E. M., Fisher, A.H., \& VanGinkel, W. P. (2009). Challenging experiences: Gender differences in task choices. Journal of Managerial Psychology, 24(1), 4-28.

Dierickx, I., \& Cool, K. (1989). Asset stock accumulation and sustainability of a competitive advantage. Management Science, 35, 1054-1513.

Druskat, V., \& Wolff, S. (1999). Effects and timing of developmental peer appraisals in self-managing work groups. Journal of Applied Psychology, 84(1), 58-74.

Dudley, N. M., Orvis, K. A., Lebiecki, J. E., \& Cortina, J. M. (2006). A meta-analytic investigation of conscientiousness in the prediction of job performance:

Examining the intercorrelations and the incremental validity of narrow traits. Journal of Applied Psychology, 91(1), 40-57.

Dzinknowski, R. (2000). The measurement and management of human intellectual capital: An introduction. Management Accounting, 73(2), 32-36.

Echols, M. (2008, September). Value creation with human capital investment. Chief learning officer. 46-51. Retrieved on May 13, 2011 at http://www.nxtbook.com/nxtbooks/mediatec/clo0908/.

Edvinsson, L., \& Malone, M. (1997), Intellectual capital. New York: Harper Collins.

Gibbons, R., \& Waldman, M. (2004). Task specific human capital. American Economic Review, 94(2), 203-207.

Goss, E. (2011, May 8). Tax hike for rich is good politics, lousy economics. Omaha World-Herald, p. 11B.

Harel, G., \& Baruch, Y. (1993). The effect of educational background on performance and organizational commitment. Human Resource Management Journal, 43(1), 78-87.

Hargis, M. B., Baltes, B. B., \& Levi, A. (2006). Race differences in termination at work: 
The role of educational inequity. Journal of Business and Psychology, 20(1), 587598.

Harlow, L. L. (2005). The essence of multivariate thinking. Mahwah, NJ: Lawrence Erlbaum.

Heneman, H. G., III, \& Judge, T. A. (2009). Staffing organizations. Middleton, WI: McGraw-Hill Irwin.

Herman, R. E., \& Gioia, J. L. (2000). How to become an employer of choice. Naperville, IL: Oak Hill.

Hough, J. (2009, March 31). On the street: The case against the college degree. Smart money. Retrieved on May 13, 2011 at http://www.smartmoney.com/personalfinance/college-planning/the-case-against-the-college-degree/\#.

Hunter, J. E. (1992). Cognitive ability, cognitive aptitudes, job knowledge, and job performance. Current Directions in Psychological Sciences, 1(1), 89-92.

Johnson, M. K., \& Elder, G. H. (2002). Educational pathways and work value trajectories. Sociological Perspectives, 45(2), 113-138.

Kanfer, R., \& Ackerman, P. L. (2004). Aging, adult development, and work motivation. Academy of Management Review, 29(3), 440-458.

Konovsky, M. A., \& Organ, D. W. (1996). Dispositional and contextual dimensions of organizational citizenship behavior. Journal of Organizational Behavior, 17(3), 253-266.

Kraaijenbrink, J., Spender, J. C., \& Groen, A. J. (2010). The resource=based view: A review and assessment of its critiques. Journal of Management, 36, 349-372.

Latham, G., \& Wexley, K. (1994). Increasing productivity through performance appraisal. Reading, MA: Addison-Wesley.

Lumina Foundation for Education (2010, January). The Degree Qualifications Profile. Retrieved on June 26, 2011 at http://www.luminafoundation.org/publications/ The_Degree_Qualifications_Profile.pdf.

Mayo, A. (2005, September). Me and my capital. Training Journal, 82-83.

McCall, H., Arnold, V., \& Sutton, S. G. (2008). Use of knowledge management systems and the impact of the acquisition of explicit knowledge. Journal of Information Systems, 22(2), 77-102.

McDermott, M., \& Samson, F. L. (2005). White racial and ethnic identity in the United States. Annual Review of Sociology, 31, 245-261.

Meyers, C., \& Conner, M. (1992). Age differences in skill acquisition and transfer in an implicit learning paradigm. Applied Cognitive Psychology, 6(2), 429-442.

Milkovich, G.T., \& Newman, J. M. (2008). Compensation. Boston, MA: McGraw-Hill Irwin.

Murray, C. A. (2008). Real education. New York, NY: Crown Forum Publishers.

$\mathrm{Ng}, \mathrm{T}$. W. H, \& Feldman, D. (2009). How broadly does education contribute to job performance. Personnel Psychology, 62(1), 89-134.

Ng, T.W. H., Eby, L.T, Sorensen, K. L., \& Feldman, D. (2005). Predictors of objective and subjective career success: A meta-analysis. Personnel Psychology, 59(2), 367-408.

Niehoff, B. P., \& Moorman, R. H. (1993). Justice as a mediator between methods of monitoring and organizational citizenship behavior. Academy of Management Journal, 36(3), 527-556. 
Nonaka, I. (2002). A dynamic theory of knowledge creation. In C. Choo \& N. Bontis (Eds.), The strategic management of intellectual capital and organizational knowledge (pp. 437 - 462). New York, NY: Oxford University Press.

Nordhaug, O. (1994). Human capital in organizations: Competence, training, and learning. New York, NY: Oxford University Press.

Oh, J., \& Shin, E. H. (2003). Inequalities in nonfatal work injury: The significance of race, human capital, and occupations. Social Science and Medicine, 57(11), 2173-2182.

Oreopoulos, P., \& Salvanes, K. G. (2011). Priceless: The nonpecuniary benefits of schooling. Journal of Economic Perspectives, 25(1), 159-184.

Organ, D. W., Padsakoff, P. M., \& MacKenzie, S. B. (2006). Organizational citizenship behavior: Its nature, antecedents, and consequence. Thousand Oaks, CA: Sage.

Penrose, E. T. (1959). The theory of the growth of the firm. New York: Oxford University Press.

Penrose, E. T. (1995). The theory of the growth of the firm ( $3^{\text {rd }}$ ed.). New York: Oxford University Press.

Pfeffer, J. 1994. Competitive advantage through people: Unleashing the power of the workforce. Boston, MA: Harvard Business School Press.

Pil, F. T., \& Leana, C. (2009). Applying organizational research to public school reform: The effects of teacher human and social capital on student performance. Academy of Management Journal, 52(6), 1101-1124.

Ployhart, R. E., \& Holtz, B. C. (2008). The diversity-validity dilemma: Strategies for reducing racioethnic and sex subgroup differences and adverse impact in selection. Personnel Psychology, 61(1), 153-172.

Ployhard, R. E., \& Moliterno, T. P. (2011). Emergence of the human capital resource: A multilevel model. Academy of Management Review, 36(1), 127-150.

Ree, M. J., Earls, J. A., \& Teachout, M. S. (1994). Predicting job performance: Not much more than g. Journal of Applied Psychology, 79(6), 518-524.

Reed, K. K., Srinivasan, N., \& Doty, D. H. (2009). Adapting human and social capital to impact performance: Some empirical findings from the U.S. personal banking sector. Journal of Managerial Issues, 21(1), 36-57.

Roberson, L., \& Block, C. J. (2001). Racioethnicity and job performance. In Staw, B. M., \& Sutton, R. I. (Eds.), Research in organizational behavior, 23, (pp. 247-326). Oxford, UK: JAI Press/Elsevier Science.

Royal, C., \& O'Donnell, L. (2008). Emerging human capital analytics for investment purposes. Journal of Intellectual Capital, 9(3), 367-379.

Samudhram, A., Shanmugam, B., \& Low, K. L. T. (2008). Valuing human resources: An analytical framework. Journal of Intellectual Capital, 9(4), 655-667.

Schmidt, F. L., \& Hunter, J. E. (1998). The validity and utility of selection methods in personnel psychology. Psychological Bulletin, 124(2), 262-274.

Sekiguchi, T., Burton, J. P., \& Sablynski, C. J. (2008). The role of job embeddedness on employee performance: The interactive effects with leader-member exchange and organization-based self-esteem. Personnel Psychology, 71(4), 761-792.

Spilerman, S., \& Lunde, T. (1991). Features of educational attainment and job promotion prospects. American Journal of Sociology, 97(3), 689-720. 
Stark, E. (2008). Facing the potential of an aged workforce and reconciling business images of peak performance, speed, and innovation. Paper presented to the sixteenth annual meeting of the Institute of Behavioral and Applied Management, Orlando, FL. October 2-4.

Stark E. (2009). Lost in a time warp: How age stereotypes impact older Baby Boomers who still want to work. People \& Strategy, 32(4), 58-64.

Tabachnick, B. G., \& Fidell, L. S. (2007). Using multivariate statistics, New York, NY: Pearson.

The Chronicle of Higher Education (2009). Are too many students going to college? (November 8). Retrieved on April 26, 2010 at chronicle.com.ezproxy.bellevue.edu/article/Are-Too-Many-StudentsGoing/49039/.

Trusty, J. T., \& Niles, S. G. (2004). Realized potential or lost talent: High school variables and bachelor's degree completion. The Career Development Quarterly, $53(1), 2-15$.

Truxillo, D. M., Bennett, S. R., \& Collins, M. L. (1998). College education and police job performance: A ten-year study. Public Personnel Management, 27(2), 269-280.

U.S. Department of Education. (2006). A test of leadership: Charting the future of U.S. higher education (September). Retrieved on February 27, 2010 at http://ed.gov/about/bdscomm/list/ hiedfuture/reports/pre-pub-report.pdf.

U. S. Department of Labor. (2009). The workforce (July). Retrieved on July 13, 2009 at http://www.dol.gov/oasam/programs/history/herman/reports/futurework/report/cha pter1/main.htm.

Van Iddekinge, C. H., \& Ployhart, R. E. (2008). Developments in the criterion-related validation of selection procedures: A critical review and recommendations for practice. Personnel Psychology, 61(4), 871-925.

Vogt, W. P. (1999) Dictionary of statistics \& methodology: A nontechnical guide for the social sciences. Thousand Oaks, CA: Sage.

Weatherly, L. A. (2003 March). Human Capital: The elusive asset. Society for Human Resource Management Research Quarterly. Retrieved on June 4, 2009 from http://www.ispi.org/pdf/suggestedReading/6_Weatherly_HumanCapital.pdf.

Wolf, A. (2002). Does education matter? Myths about education and economic growth. London, UK: Penguin Books.

Wolf, A. (2011, June). Hollowing out the ivory tower: Alison Wolf on the crisis of the university. Spiked, Issue 45. Retrieved on June 27, 2011, at http://www.spikedonline.com/index.php/site/reviewofbooks_article/10638/

Wong, C., \& Cho, C. E. (2005). Two-headed coins or Kandinskys: White racial identification. Political Psychology, 26(5) 699-721. 